\title{
\begin{tabular}{l|l|l} 
jurnal & Jurnal Kependidikan Dasar & $\begin{array}{l}\text { Volume 6 } \\
\text { Nomor 2 } \\
\text { Tohis } 2021\end{array}$ \\
\hline
\end{tabular}
}

\section{IMPLEMENTASI PEMBELAJARAN JARAK JAUH DENGAN MEDIA E-LEARNING (STUDI DI MADRASAH IBTIDAIYAH NEGERI 7 PONOROGO)}

\author{
Anis Afifah \\ Institut Agama Islam Negeri Ponorogo \\ Surel: afifah@iainponorogo.ac.id
}

\begin{abstract}
Abstrak
Kehadiran E-Learning madsarah sebagai salah satu alternatif media pembelajaran jarak jauh yang digagas oleh Direktorat Kurikulum Sarana Kelembagaan dan Kesiswaan MadrasahKementrian Agama Republik Indonesia harus diiringi dengan kesiapan guru dalam merencanakan pembelajaran. Artikel ini bermaksud untuk menganalisis implementasi pembelajaran jarak jauh dengan media E-Learning pada tahap perencanaan pembelajaran. Jenis penelitian yang digunakan adalah single-case study yaitu penelitian yang dilakukan di MIN 7 Ponorogo sebagai salah satu madrasah yang aktif dalam mengembangkan E-Learning Madrasah. Teknik pengumpulan dan analisis data menggunakan model Matthew B. Miles and A. Michael Huberman. Analisis mengacu pada konsep desain instructional Morison and Kemp yang terdiri dari empat elemen, yaitu identifikasi tujuan pembelajaran, analisis peserta didik, metode pembelajaran dan evaluasi pembelajaran. Hasil penelitian menunjukkan bahwa perencanaan pembelajaran dengan menggunakan E-Learning disusun secara sistematis sesuai dengan kurikulum yang berlaku, menyesuikan dengan kebutuhan serta kondisi peserta didik, menggunakan metode ceramah, diskusi dan penugasan. Evaluasi pembelajaran dilakukan secara berkala dan berkesinambungan sesuai dengan jadwal yang telah ditetapkan oleh madrasah.
\end{abstract}

Kata Kunci: e-learning, perencanaan pembelajaran, pembelajaran jarak jauh

\begin{abstract}
The presence of Madrasah E-Learning as one of the alternative distance learning media initiated by the Directorate of Institutional and Student Facilities Curriculum for Madrasah Ministry of Religion of the Republic of Indonesia must be accompanied by teacher readiness in planning learning. This article intends to analyze of distance learning planning with E-Learning media at the learning planning stage. The type of research used is a single-case study, namely research conducted at MIN 7 Ponorogo as one of the madrasas that is active in developing Madrasah E-Learning. Data collection and analysis techniques used the model of Matthew B. Miles and A. Michael Huberman. The analysis refers to Morison and Kemp's instructional design concept which consists of four elements, namely identification of learning objectives, student analysis, learning methods and learning evaluation. The results showed that learning planning using E-Learning was arranged systematically in accordance with the applicable curriculum, adjusting to the needs and conditions of students, using lecture, discussion and assignment methods. Learning evaluation is carried out periodically and continuously according to the schedule set by the madrasah.
\end{abstract}


Keywords: e-learning, learning planning, distance learning

\section{A. PENDAHULUAN}

Sejak dikeluarkannya Surat Edaran Menteri Pendidikan dan Kebudayaan Republik Indonesia tentang kebijakan pendidikan dalam masa darurat penyebaran Covid-19, kegiatan belajar mengajar dilakukan dalam bentuk kegiatan belajar dari rumah. Kegiatan ini diupayakan untuk memberikan pengalaman yang bermakna bagi siswa, fokus pada pendidikan kecakapan hidup, aktivitas pembelajaran yang variatif dan umpanbalik proses pembelajaran yang bersifat kualitatif. ${ }^{1}$ Pembelajaran yang awalnya tatap muka beralih ke pembelajaran jarak jauh. Hal ini terjadi mulai dari jenjang pendidikan dasar, sampai perguruan tinggi. Berdasarkan hasil penelitian yang dilakukan pada guru di empat jenjang pendidikan di kota Riau menunjukkan sebesar 35\% guru belum siap untuk melaksanakan Pendidikan jarak jauh. ${ }^{2}$

Direktorat Kurikulum Sarana Kelembagaan dan Kesiswaan Madrasah Kementrian Agama Republik Indonesia (KSKKM Kemenag RI) telah menerapkan pembelajaran melalui media E-Learning Madrasah sebagaimana dirilis oleh Kompas.com pada bulan Maret tahun 2020. E-Learning Madrasah dapat diakses melalui laman https://elearning.kemenag.go.id/ oleh seluruh madrasah di Indonesia mulai dari madrasah ibtidaiyah, madrasah tsanawiyah, dan madrasah aliyah baik negeri maupun swasta. Berdasarkan data statistik pengguna pada laman E-Learning Kemenag, sebanyak 27.278 atau 51,88\% dari jumlah madsarah yang terdata pada EMIS telah menggunakan E-Learning Madrasah sebagai media pembelajaran jarak jauh. Hasil penelitian menunjukkan E-Learning Madrasah merupakan salah satu media pembelajaran jarak jauh yang baik, meskipun kendala jaringan yang belum stabil di daerah terpencil Indonesia masih menjadi hambatannya. ${ }^{3}$ Sejalan dengan itu perlu adanya kesiapan dan peningkatan kapasitas guru dalam merencanakan pembelajaran menggunakan media E-Learning madrasah. Perencanaan pembelajaran disusun berdasarkan tujuan, kondisi siswa, serta kesesuaian metode dan evaluasi pembelajaran

Sejauh ini studi tentang pembelajaran jarak jauh di tingkat pendidikan dasarsebatas pada implementasi pembelajaran jarak jauhdan kendalanya. Pelaksanaan pembelajaran jarak jauh dilakukan melalui berbagai macam aplikasi diantaranya WhatApps, Google Classrom, Zoom Meating. ${ }^{4}$ Selain kendala jaringan internet implementsai pembelajaran

1 "Mentri Pendidikan dan Kebudayaan Surat Edaran Nomor 4 Tahun 2020 tentang Pelaksanaan Pendidikan Masa Darurat Penyebaran Corona Virus Disease (Covid-19)," March 24, 2020.

2 Muhaiminah Jalal, “Kesiapan Guru Menghadapi Pembelajaran Jarak Jauh di Masa Covid-19," SMART KIDS: Jurnal Pendidikan Islam Anak Usia Dini 2, no. 1 (2020): 35-40.

${ }^{3}$ Husnul Khotimah et al., "E-Learning Application Madrasah Online Learning Solution in the Middle of Pandemic Covid-19 in MA Negeri Insan Cendekia, Kendari," Technium Social Sciences Journal 10 (2020): 107.

4 Andri Anugrahana, "Hambatan, Solusi dan Harapan: Pembelajaran Daring selama Masa Pandemi Covid-19 oleh Guru Sekolah Dasar," Scholaria: Jurnal Pendidikan Dan Kebudayaan 10, No. 3 (2020): 282-89; Arwidana Putra Krismadika dan Achmad Fathoni, "Implementasi Pembelajaran Jarak Jauh Selama Pandemi Covid-19 di SD IT Al-Huda Wonogiri” (PhD Thesis, Universitas Muhammadiyah Surakarta, 2020); Nursafitri 
terkendala pada pengelolaan pembelajaran yang dinilai masih sukar oleh guru serta kurangnya pengasawan orang tua. ${ }^{5}$ Peran guru dalam pembelajaran jarak jauh sebagai perencana, peleksana, evaluator dan motivator dalam pembelajaran. ${ }^{6}$ Serta respon peserta didik pada kegiatan pembelajaran jarak jauh yang menyatakan pembejalaran menggunakan E-Learning menarik dan tidak membosankan. ${ }^{7}$ Tanggapan positif pelaksanaan pembelajaran jarak jauh oleh guru dan peserta sebagai upaya pencegahan penyebaran covid-19, seyogyanya diiringi dengan kesiapan guru dalam pembelajaran yang terimplementasi pada kegiatan perencanaan pembelajaran. Hasil penelitian menunjukkan bahwa perlu memperkenalkan E-Learning pada pembelajaran jarak jauh sehingga terjalin komunikasi dua arah antara guru dan siswa. ${ }^{8}$ Selain itu sekolah sebagai sarana integrasi sosial perlu membangun interaksi antar siswa. ${ }^{9}$

Tulisan ini ditujukan untuk menganalisis kegiatan perencanaan pembelajaran oleh guru dalam pembelajaran jarak jauh menggunakan media E-Learning di Madrasah Ibtidaiyah Negeri (MIN) 7 Ponorogo. Hasil analisis akan memberikan gambaran tentang perencanaan pembelajaran jarak jauh dengan media E-Learning Madrsah. Tulisan didasarkan pada argumen bahwa perencanaan pembelajaran jarak jauh di tingkat pendidikan dasar perlu dipersiapkan dengan seksama, sehingga tujuan pembelajaran dapat tercapai secara maksimal, peserta didik dapat memperoleh pengalaman belajar sesuai denngan tujuan pembelajaran yang hendak dicapai. Metode pembelajaran yang digunakan sesuai dengan situasi yang terjadi. Evaluasi dapat mengukur keberhasilan pembelajaran secara efektif dan efisien

Nursafitri, Yantoro Yantoro, and Faizal Chan, "Peran Guru pada Pembelajaran Jarak Jauh di Masa Pandemi Covid-19 di Sekolah Dasar" (PhD Thesis, Universitas Jambi, 2021); Kurnia Dwi Setyaningsih, "Analisis Pelaksanaan Pembelajaran Jarak Jauh di SD Negeri Karangrena 03," Jurnal Riset Pendidikan Dasar (JRPD) 1, no. 2 (2020); Icha Permata Sari, “Analisis Pelaksanaan Pembelajaran Jarak Jauh terhadap Siswa SD," in Prosiding Seminar Nasional Pendidikan, Vol. 3, 2021, 8-13.

5 Henry Aditia Rigianti and PGSD Prosa, "Kendala Pembelajaran Daring Guru Sekolah Dasar Di Kabupaten Banjarnegara," 2020.

6 Siti Sabaniah, Dadan F. Ramdhan, and Siti Khozanatu Rohmah, "Peran Guru Dalam Pelaksanaan Pembelajaran Jarak Jauh Di Tengah Wabah Covid-19," Edunesia: Jurnal Ilmiah Pendidikan 2, no. 1 (2021): 4354.

${ }^{7}$ Purniawan Purniawan and Woro Sumarni, “Analisis Respon Siswa Pada Pembelajaran Daring Di Masa Pandemi Covid 19," in Prosiding Seminar Nasional Pascasarjana (PROSNAMPAS), vol. 3, 2020, 784-89; A. N. Sobron and Rani Bayu, "Persepsi Siswa Dalam Studi Pengaruh Daring Learning Terhadap Minat Belajar Ipa," SCAFFOLDING: Jurnal Pendidikan Islam Dan Multikulturalisme 1, no. 2 (2019): 30-38.

8 Gulnara M. Burdina, Irina E. Krapotkina, and Liliya G. Nasyrova, "Distance Learning in Elementary School Classrooms: An Emerging Framework for Contemporary Practice," International Journal of Instruction 12, no. 1 (January 2019): 1-16.

9 Panagiotes S. Anastasiades, "Distance Learning in Elementary Schools in Cyprus: The Evaluation Methodology and Results," Computers \& Education 40, no. 1 (January 1, 2003): 17-40, https://doi.org/10.1016/S0360-1315(02)00077-5. 


\section{B. METODE PENELITIAN}

Penelitian ini menggunakan pendekatan kualitatif dengan jenis single-case study, yaitu desain penelitian yang digunakan untuk meneliti satu kasus atau subjek penelitian ${ }^{10}$, dalam hal ini adalah kasus tentang perencanaan pembelajaran menggunakan E-Learning di MIN 7 Ponorogo. Sumber dan jenis data dalam penelitian ini berupa: kata-kata dari proses wawancara dengan Bapak Sidik selaku pengembang E-Learning MIN 7 Ponorogo, tindakan yang dilakukan oleh guru MIN 7 Ponorogo dalam merencanakan pembelajaran jarak jauh menggunakan media E-Learning, dokumentasi E-Learning MIN 7 Ponorogo.

Teknik pengumpulan dan analisis data dalam penelitian ini menggunakan model Matthew B. Miles and A. Michael Huberman, yaknidata collection, data reduktion, data display, dan conclusion. ${ }^{11}$ Pengumpulan data (data collection)dilakukan melalui tiga teknik pengumpulan data yakni teknik wawancara tidak terstruktur terkait dengan perencanaan pembelajaran menggunakan E-Learning Madrasah yang dikembangkan oleh Direktorat KSKKM Kemenag RI. Wawancara dilakukan kepada kepala madrsah, dan guru yang menggunakan dan mengembangkan E-Learning Madrasah dalam kegiatan pembelajaran. Teknik observasi dan dokumentasi pada laman E-Learning MIN 7 Ponorogo. Reduksi data (data reduction) dengan memilah data teori desain pembelajaran Morison and Kemp. Penyajian data (data display) dalam bentuk deskripsi serta gambar dan penarikan kesimpulan tentang perencanaan pembelajaran menggunakan media E-Learning di MIN 7 Ponorogo.

\section{HASIL DAN PEMBAHASAN}

\section{PERENCANAAN PEMBELAJARAN JARAK JAUH DENGAN MEDIA E-LEARNING DI MIN 7 PONOROGO}

Menurut Morison dan Kemp perencanaan pembelajaran diidentifikasi melalui empat elemen dasar. Keempat elemen tersebut adalah tujuan pembelajaran, peserta didik, metode dan evaluasi. ${ }^{12}$ Tujuan pembelajaran memuat tentang apa yang ingin dipelajari dalam sebuah pembelajaran. Peserta didik merupakan sasaran utama program pembelajaran. Metode merupakan cara bagaimana materi pembelajaran disampaikan. Evaluasi dilakukan untuk memastikan apakah konsep yang diajarkan oleh guru dapat diterima oleh peserta didik.

\section{Identifikasi Tujuan Pembelajaran Jarak Jauh di MIN 7 Ponorogo}

Identifikasi tujuan pembelajaran dilakukan untuk menentukan konsep yang akan diajarkan pada siswa. Identifikasi tujuan pembelajaran dilakukan berdarkan pada

${ }^{10}$ Michael Hauberman dan Matthew B. Miles, The Qualitative Researcher's Companion (Sage, 2002$), 11$.

11 Matthew B. Miles dan A. Michael Huberman, Qualitative Data Analysis: An Expanded Sourcebook (sage, 1994), 12.

${ }^{12}$ Gary R. Morrison et al., Designing Effective Instruction (United States Of Amarica: John Wiley \& Sons, Inc., 2011), 14. 
Komptensi Inti (KI) dan Kompetensi Dasar (KD) pelajaran pada Kurikulum 2013 pada Pendidikan Anak Usia Dini, Pendidikan Dasar, dan Pendidikan Menengah Berbentuk Sekolah Menengah Atas Untuk Kondisi Khusus ${ }^{13}$ dan Kurikulum Pendidikan Agama Islam dan Bahasa Arab pada Madrasah. ${ }^{14}$ Berdarakan dua aturan tersebut guru mengidentifikasi dan mengembangkan tujuan pembelajaran, menentukan indikator pembelajaran menentukan materi pembelajaran yang sesuai dengan tujuan pembelajaran dan selanjutnya disusun dalam Rencana Perangkat Pembelajaran (RPP).

Hal spesifik yang membedakan pada rencana pembelajaran pada masa pandemic dengan pembelajaran sebelum pandemi ini adalaha lokasi waktu pembelajaran. Jika pada pembelajaran dengan tatap muka terdapat alokasi waktu pembelajaran, akan tetapi pada pembelajaran jarak jauh dengan menggunakan E-Learning Madrasah lebih bersifat fleksibel. Artinya siswa dapat mengakses laman E-Learning Madrasah selama 24 Jam. Fleksibilitas waktu akses E-Learning Madrasah ini merupakan upaya guru dalam mengatasi hambatan ketersediaan perangkat pengakses (hand phone ataupun laptop) serta keberadaan orang tua sebagai pembimbing dan pengawas pada kegiatan pembelajaran jarak jauh. ${ }^{15}$

Pada kegiatan pembelajaran jarak jauh tujuan pembelajaran di MIN 7 Ponorogo senantiasa diidentifikasi oleh guru dan dikembangkan berdasarkan kondisi yang terjadi sesuai perkembangan lingkungan terkait pandemi covid-19. Salah satu pengembangan yang dilakukan adalah upaya mencegahan covid-19 dengan pembiasaan protokol Kesehatan mencuci tangan, memakai masker, menjaga jarak, menjauhi kerumunan, dan mengurangi mobilitas. Selain hal tersebut siswa juga dibiasakan untuk sholat subuh berjamaah bersama dengan orang tua. Kegiatan pembiasaan ini menggantikan kegiatan pembiasaan salam, sapa, senyum yang dilakukan selama kegiatan pembelajaran tatap muka. Adapun kegiatan pembiasaan yang tetap dipertahankan baik pada kegiatan pembelajaran tatap muka atau kegiatan pembelajaran jarak jauh adalah kebiasaan sholat dhuha, membaca alqur'an sebelum pembelajaran serta menjaga kebersihan. Akan tetapi dalam pengawasannya dilakukan oleh orang tua.

Kegiatan pembelajaran seperti halnya percobaan dilakukan secara mandiri oleh siswa dengan menggunakan alat dan bahan yang tersedia di lingkungan sekitar siswa. Beberapa kegiatan praktik dilakukan oleh siswa dalam pengawasan orang tua. Rencana pembelajaran yang disusun oleh guru diunggah pada laman E-Learning MIN 7 Ponorogo pada menu Rencana Pembelajaran dengan harapan orang tua dapat mengakses dan dapat mengarahkan putra-putrinya dalam kegiatan pembelajaran.

13 "Mentri Pendidikan dan Kebudayaan Surat Edaran Nomor 4 Tahun 2020 tentang Pelaksanaan Pendidikan Masa Darurat Penyebaran Corona Virus Disease (Covid-19)," March 24, 2020.

14 "KMA No 183 Tahun 2019 Tentang Kurikulum Pendidikan Agama Islam (PAI) Dan Bahasa Arab Pada Madrasah.Pdf," n.d., accessed November 7, 2021.

15 Anugrahana, "Hambatan, Solusi dan Harapan"; Henry Aditia Rigianti, "Kendala Pembelajaran Daring Guru Sekolah Dasar di Banjarnegara," Elementary School: Jurnal Pendidikan Dan Pembelajaran Ke-Sd-An 7, no. 2 (2020). 


\section{Analisis Karakter dan Kebutuhan Peserta Didik Menggunakan Media E-Learning}

Analisis karakter dan kebutuhan peserta didik dapat dilihat dari tingkat kehadiran pada laman E-Learning selama pembelajaran. Menu absensi kelas dapat digunakan sebagai alat bantu untuk menganalisis karakter dan kebutuhan peserta didik.

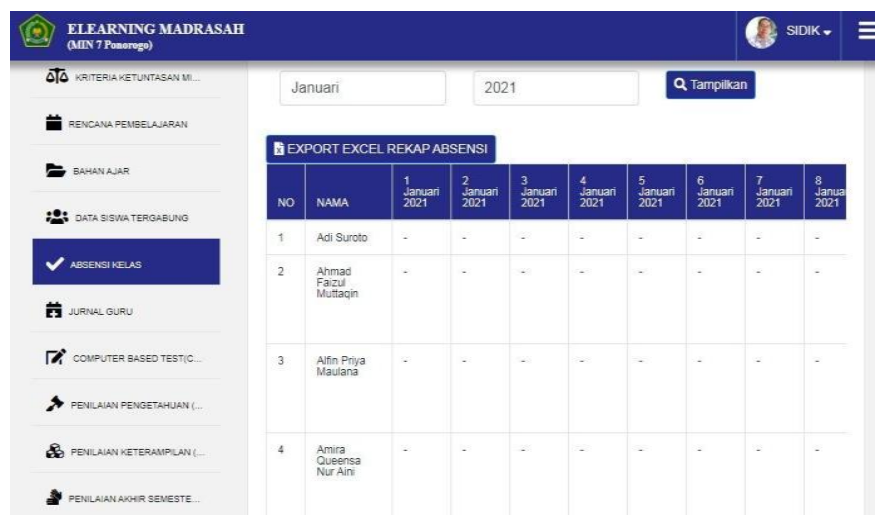

\section{Gambar 1. Tampilan absen siswa pada laman E-Learning MIN 7 Ponorogo}

Data kehadiran siswa menunjukkan bahwa siswa tingkat kesulitan serta minat siswa dalam mengakses E-Learning Madrasah. Waktu pengisian absensi siswa pada absen $E$ Learning Madrasah menjadi indicator kapan siswa bisa mengakses E-Learning. Karakter kedisiplinan dapat dipantau dari ketepatan waktu dalam pengisian absensi siswa ini. Akan tetapi untuk mengetahui karakter dan kebutuhan peserta didik pada pembelajaran jarak jauh secara lebih mendalam tidak dapat maksimal dilihat dari tingkat kehadiran saja. Guru juga melakukan analisis karakter dan kebutuhan siswa melalui observasi pada diskusi saat pembelajaran dengan menggunakan menu Video Conference, dan juga melakukan wawancara personal dengan wali murid menggunakan panggilanWhatsApps.

\section{Metode Pembelajaran Jarak Jauh MIN 7 Ponorogo Menggunakan E-Learning}

Pembelajaran Jarak Jauh MIN 7 Ponorogo diimlepentasikan melalui penggunaan media E-Learning madrasah. Media E-Learning MIN 7 Ponorogo dirancangan dengan mengembangan Platform E-Learning Madrasah disediakan oleh Direktorat KSSK Madrasah Kementerian Agama RI. E-Learning Madrasah menggunakan versi 4.5.1. Siswa dan guru dapat mengakses E-Learning diakses melalui laman https://elearning.kemenag.go.id/dengan perangkat handphone, komputer ataupun menggunakan laptop. Setiap siswa dan guru di MIN 7 Ponorogo diberikan user-id dan password oleh operator madrasah untuk dapat mengkases platform ini.

Media E-Learning MIN 7 Ponorogo dikembangkan dengan menyediakan menu Forum Madrasah, Time Line Kelas, Video Conference, Standar Kompetensi, Kriteria Ketuntasan, Perencanaan Pembelajaran, Bahan Ajar, Data Siswa Tergabung, Absensi Mahasiswa, dan Jurnal Guru, Computer Based Test, Penilaian Pengetahuan, Penilaian Ketrampilan, Penilaian Akhir Semester, Rekap Nilai Raport, Monitoring Aktivitas Siswa, 
Kalender Kelas, Pengaturan Kelas dan Hapus Kelas. Masing-masing fitur dapat diakses oleh operator, guru, dan siswa sesuai dengan fungsi yang telah diprogram operator madrasah. Pengembangan fitur E-Learning Madrasah dilakukan berdasar pada Buku Petunjuk Penggunaan Website E-learning Madrasah yang diterbitkan oleh Kementrian Agama. ${ }^{16}$

Beberapa metode yang digunakan dalam pembelajaran jarak jauh dengan media $E$ Learning MIN 7 Ponorogo ini antara lain ceramah, diskusi dan penugasan. Metode ceramah merupakan penyampaian materi melalui penuturan lisan secara langsung kepada peserta didik. ${ }^{17}$ Perencanaan metode pembelajaran ceramah pada kegiatan pembelajaran jarak jauh dilakukan dengan mengunggah video ceramah yang dilakukan oleh guru pada pagianbahan ajar sebagaimana gambar berikut:

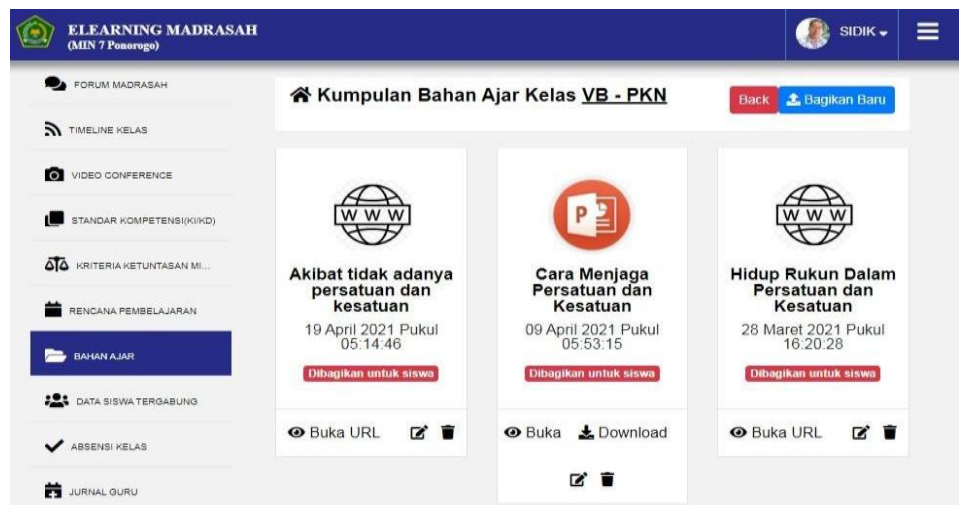

\section{Gambar 2. Tampilan bahan ajar guru pada laman E-Learning MIN 7 Ponorogo}

Selain video ceramah pada menu bahan ajar ini guru juga mengunggah PPT, modul pembelajaran, lembar kerja dan beberapa referensi yang dapat digunakan siswa sebagai sumber belajar siswa.

Metode diskusi pada pembelajaran jarak jauh menggunakan media E-Learning dilakukan pada menu Video Conference. Pada menu ini siswa dan guru dapat melakukan tatap maya sesuai dengan waktu yang telah direncanakan. Untuk melakukan video conference siswa dan guru membuat kesepakatan pada hari sebelumnya. Hal ini dilakukan oleh guru agar siswa mempersiapakan diri, terutama bagi siswa menggunakan yang fasilitas Hand Phone milik orang tua.

Metode penugasan dilakukan guru untuk memperdalam konsep yang dibelajarkan pada setiap mata pelajaran. Penugasan dapat berupa latihan soal, atau pun praktik pembelajaran. Tagihan dalam metode penugasan ini berupa foto hasil pekerjaan, video praktik, video kegiatan observasi dan lembar obervasi yang telah diisi oleh siswa serta penugasan lainnya yang diunggah pada bagian tugas E-Learning masing-masing siswa.

16 Kemengtrian Agama, "Panduan E-Learning Madrasah," 2019.

17 Syahraini Tambak, "Metode Ceramah: Konsep dan Aplikasi dalam Pembelajaran Pendidikan Agama Islam,” JURNAL TARBIYAH 21, no. 2 (December 1, 2014), https://doi.org/10.30829/tar.v21i2.16. 
Setiap hari guru akan menyapa siswa melalui menu Time Line. Guru akan menuliskan instruksi apa saja yang harus dilakukan siswa dalam satu hari, sesuai dengan jadwal pelajaran yang telah dibagikan sebelumnya.

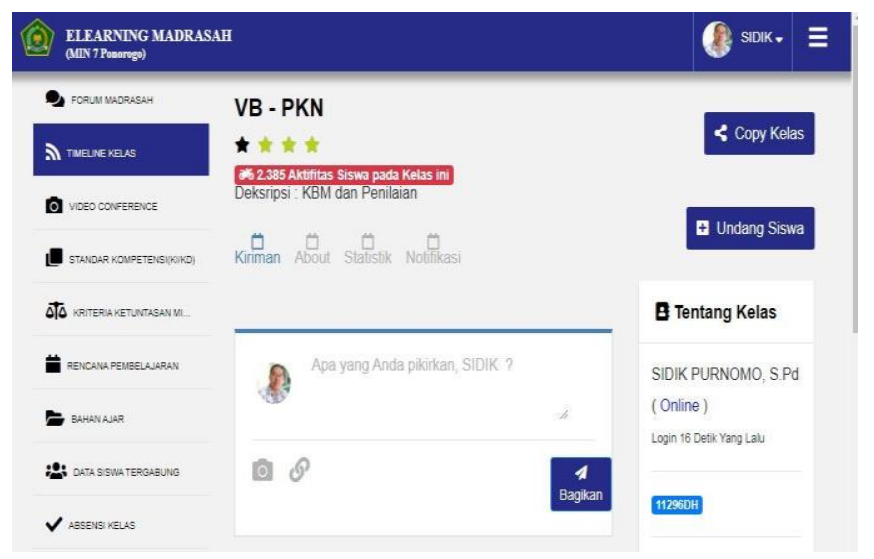

Gambar 3. Tampilan Menu Time Line pada laman E-Learning MIN 7 Ponorogo

\section{Evaluasi Hasil Belajar pada Pembelajaran Jarak Jauh dengan Media E-Learning di MIN 7 Ponorogo}

Evaluasi hasil belajar menjadi aspek yang integral dalam penyusunan perencanaan pembelajaran. Evaluasi dilakukan untuk memastikan memastikan apakah konsep yang diajarkan oleh guru dapat diterima oleh peserta didik. Evaluasi pembelajaran dirancang untuk mengetahui sejauh mana pembelajaran dicapai. Instrumen evaluasi yang disusun digunakan untuk mengasessemen penguasaan pembelajaran siswa. ${ }^{18}$ Pelaksanaan evaluasi hasil belajar pada pembelajaran jarak jauh dengan media E-Learning di MIN 7 Ponorogo dirancang guru dengan mengklasifikasikan pada tiga macam menu pada laman E-Learning Madrasah penilaian pengetahuan, penilaian ketrampilan dan penilaian semester. Penilaian pengetahuan dan Penilaian Keterampilan disusun setiap akhir tema pembelajaran. Penilaian pengetahuan dilakukan dengan memberikan soal atau kuis. Sedangkan penilaian ketrampilan dilakukan dengan memberikan tugas praktik baik yang dikirim melalui video atau melalui conference video.

Penilaian semester dilakukan sesuai dengan jadwal yang telah ditetapkan madrasah. Pemberitahuan tentang penilaian semester dilakukan pada menu time line, dan soal evaluasi diunggah pada menu penilaian semester.

${ }^{18}$ Gary R. Morrison et al., Designing Effective Instruction, 17. 


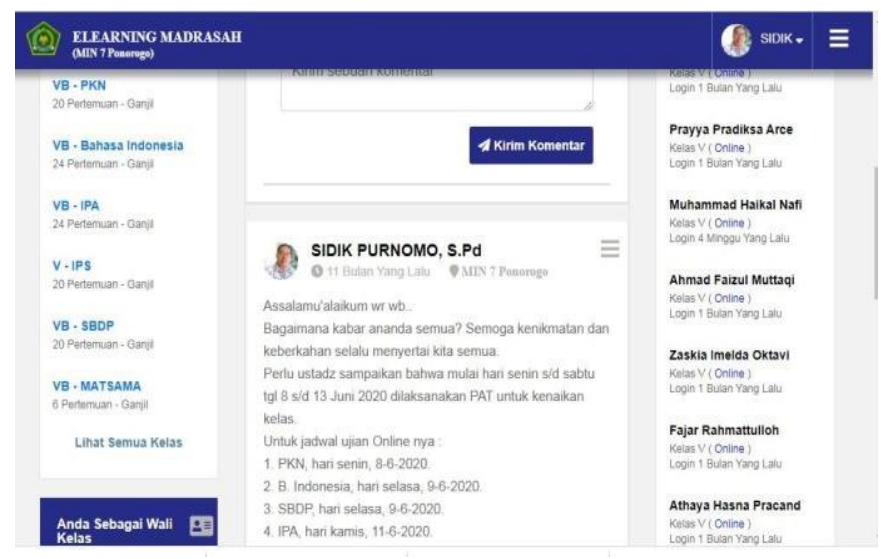

Gambar 4. Tampilan Penilaian Siswa pada laman E-Learning MIN 7 Ponorogo

Hasil penilaian pembelajaran siswa dalam satu semester diunggah oleh guru kelas pada menu Rekap Nilai Raport. Menu ini sekaligus dirancang sebagai bentuk laporan perkembangan siswa kepada wali murid dalam bentuk online.

\section{PENUTUP}

\section{Simpulan}

Perencanaan pebelajaran jarak jauh menggunakan media E-Learning Madrasah di MIN 7 Ponorogo dirancang dengan menekankan pada empat komponen, yaitu identifikasi tujuan pembelajaran yang terdapat pada kurikulum dengan menyesuaikan dengan lingkungan peserta didik sebagai upaya pencegahan penyebaran covid-19. Analisis karakter dan kebutuhan peserta didik ditekankan pada keberadaan orang tua, sebagai pendamping pembelajaran dan ketersediaan sarana pengakses E-Learning. Metodepembelajaran yang digunakan semaksimal mungkin diupayakan guru menggunakan metode pembelajaran yang menyenangkan dan kontekstual. Evaluasi pembelajaran disusun untuk mengetahui ketercapaian tujuan pembelajaran oleh siswa dan dilakukan secara berkala sesuai dengan program madrasah.

\section{Saran}

Merujuk dari temuan di atas peneliti menyarankan dalam konteks praktis kepada pemangku kepentigan untuk melakukan pelatihan dan pendampingan bagi guru untuk mengembangkan E-Learning madrasah.

\section{E. DAFTAR PUSTAKA}

Anastasiades, Panagiotes S. "Distance Learning in Elementary Schools in Cyprus: The Evaluation Methodology and Results." Computers \& Education 40, no. 1 (January 1, 2003): 17-40. https://doi.org/10.1016/S0360-1315(02)00077-5. 
Anugrahana, Andri. "Hambatan, Solusi dan Harapan: Pembelajaran Daring selama Masa Pandemi Covid-19 oleh Guru Sekolah Dasar." Scholaria: Jurnal Pendidikan dan Kebudayaan 10, No. 3 (2020): 282-89.

Burdina, Gulnara M., Irina E. Krapotkina, and Liliya G. Nasyrova. "Distance Learning in Elementary School Classrooms: An Emerging Framework for Contemporary Practice." International Journal of Instruction 12, No. 1 (January 2019): 1-16.

Gary R. Morrison, Steven M. Rose, Howard K Kalman, dan Jerrold E. Kemp. Designing Effective Instruction. United States Of Amarica: John Wiley \& Sons, Inc., 2011.

Huberman, Michael, dan Matthew B. Miles. The Qualitative Researcher's Companion. Sage, 2002.

Jalal, Muhaiminah. "Kesiapan Guru Menghadapi Pembelajaran Jarak Jauh di Masa Covid19." SMART KIDS: Jurnal Pendidikan Islam Anak Usia Dini 2, No. 1 (2020): 35-40.

Kemengtrian Agama. "Panduan E-Learning Madrasah," 2019.

Khotimah, Husnul, Husniyatus Salamah Zainiyati, Abdulloh Hamid, dan Abdul Basit. "ELearning Application Madrasah Online Learning Solution in the Middle of Pandemic Covid-19 in MA Negeri Insan Cendekia, Kendari." Technium Social Sciences Journal 10 (2020): 107.

"KMA No 183 Tahun 2019 Tentang Kurikulum Pendidikan Agama Islam (PAI) Dan Bahasa Arab Pada Madrasah.Pdf," n.d. Accessed November 7, 2021.

Krismadika, Arwidana Putra, and Achmad Fathoni. "Implementasi Pembelajaran Jarak Jauh Selama Pandemi Covid-19 di SD IT Al-Huda Wonogiri." PhD Thesis, Universitas Muhammadiyah Surakarta, 2020.

"Mentri Pendidikan dan Kebudayaan Surat Edaran Nomor 4 Tahun 2020 Tentang Pelaksanaan Pendidikan Masa Darurat Penyebaran Corona Virus Disease (Covid-19)," March 24, 2020.

Miles, Matthew B., and A. Michael Huberman. Qualitative Data Analysis: An Expanded Sourcebook. sage, 1994.

Nursafitri, Nursafitri, Yantoro Yantoro, dan Faizal Chan. "Peran Guru Pada Pembelajaran Jarak Jauh Dimasa Pandemi Covid-19 Di Sekolah Dasar." PhD Thesis, Universitas Jambi, 2021.

Purniawan, Purniawan, dan Woro Sumarni. "Analisis Respon Siswa pada Pembelajaran Daring Di Masa Pandemi Covid 19." In Prosiding Seminar Nasional Pascasarjana (PROSNAMPAS), 3:784-89, 2020.

Rigianti, Henry Aditia. "Kendala Pembelajaran Daring Guru Sekolah Dasar di Banjarnegara." Elementary School: Jurnal Pendidikan Dan Pembelajaran Ke-Sd-An 7, no. 2 (2020).

Rigianti, Henry Aditia, dan PGSD Prosa. "Kendala Pembelajaran Daring Guru Sekolah Dasar di Kabupaten Banjarnegara," 2020.

Sabaniah, Siti, Dadan F. Ramdhan, dan Siti Khozanatu Rohmah. "Peran Guru dalam Pelaksanaan Pembelajaran Jarak Jauh di Tengah Wabah Covid-19.” Edunesia: Jurnal Ilmiah Pendidikan 2, no. 1 (2021): 43-54. 
Sari, Icha Permata. "Analisis Pelaksanaan Pembelajaran Jarak Jauh terhadap Siswa SD.” In Prosiding Seminar Nasional Pendidikan, 3:8-13, 2021.

Setyaningsih, Kurnia Dwi. "Analisis Pelaksanaan Pembelajaran Jarak Jauh di SD Negeri Karangrena 03." Jurnal Riset Pendidikan Dasar (JRPD) 1, no. 2 (2020).

Sobron, A. N., dan Rani Bayu. "Persepsi Siswa dalam Studi Pengaruh Daring Learning Terhadap Minat Belajar IPA." SCAFFOLDING: Jurnal Pendidikan Islam Dan Multikulturalisme 1, no. 2 (2019): 30-38.

Tambak, Syahraini. "Metode Ceramah: Konsep dan Aplikasi dalam Pembelajaran Pendidikan Agama Islam." JURNAL TARBIYAH 21, no. 2 (December 1, 2014). https://doi.org/10.30829/tar.v21i2.16. 
176 | ibriez | Junal Kependidikan Dasar | Vol 6 No 2 Tahun 2021 